New projects flood Japan

\section{Tokyo}

JAPAN's ministries and agencies last week bombarded the Ministry of Finance with new projects related to research on the global environment in their budget proposals for the next fiscal year. Several of the requests are to establish new research centres, the biggest of which will be a new institute financed by the Ministry of International Trade and Industry (MITI) to develop "environment-friendly" technology.

The budget will not be finalized until the end of this year but requests related to science and technology usually undergo only minor adjustments in the end-of-year negotiations.

MITI has asked for $¥ 8,540$ million ( $\$ 60$ million) to set up the 'Industrial Technology Research Institute on the Global Environment', an enormous request for the first year of a new project. MITI hopes to plough about $¥ 2,000$ million of this into development of substitutes for chlorofluorocarbons and into methods of converting carbon dioxide into useful products. Both chemical and biological carbondioxide fixation will be studied, according to Hiroshi Asahi, deputy director of MITI's Environmental Protection Division.

The new institute will also develop biodegradable plastics and use biological reactions to produce useful chemical materials, Asahi says. He expects the institute to be staffed by about 50 researchers from industry and MITI's national research laboratories in its first year. And he says that MITI hopes industry will provide about one-third of the costs of joint development programmes which will run for three to five years.

The Environment Agency, which survives on a budget about one-twentieth that of MITI, wants almost to treble its outlays for global environment research to $¥ 2,400$ million ( $\$ 17$ million). Half of this sum will provide new funds to promote research on the global environment in universities and research institutes both in Japan and overseas. But the agency is not sure how it will channel funds to foreign researchers. The accounting is a "difficult problem", says Yasuo Takahashi, section chief of MITI's Environmental Research and Technology Division.

The agency has also requested $¥ 423$ million to establish a new centre for global environment research at its National Institute for Environmental Studies in Tsukuba. The centre will have a permanent staff of between 10 and 15 , as well as guest researchers, and agency officials hope to lease a supercomputer. The centre will concentrate on monitoring environmental problems in the AsiaPacific region, Takahashi says.

The Science and Technology Agency

also wants to reorganize its National Research Center for Disaster Prevention in Tusukuba, to incorporate global environment research and has requested $¥ 194$ million to do so. And the agency hopes almost to double its outlay for remote sensing of the Earth $(¥ 4,190$ million), including development of the advanced Earth Observation Satellite (ADEOS) which is scheduled for launch in the mid-1990s.

The Ministry of Foreign Affairs seems set to get the biggest percentage increases in budget with a request of $¥ 534,000$ million, nearly 15 per cent up on last year. Most of the request is for Overseas Development Aid (ODA), a large percentage of which is earmarked for protection of the global environment. At the Paris summit in July, former Prime Minister Sousuke Uno pledged to spend $¥ 300,000$ million $(\$ 2,000$ million) of ODA on the environment over the next three years. But Japanese ODA organizations are notoriously understaffed and lacking in environmental expertise.

The foreign ministry and the Ministry of Agriculture, Forestry and Fisheries have requested a combined total of about $\$ 10$ million for the International Tropical

\title{
US agencies unite on planet Earth
}

\section{Washington}

IN an attempt to integrate the key questions concerning global change and to develop a coordinated research programme, the US administration last week released a comprehensive plan setting research priorities for the study of planet Earth. The 196-page plan's key feature is that it is a cooperative effort from all of the seven US federal agencies involved in global change research.

It is the first time that they have all sat down together, shown each other their programmes and agreed to work together to "monitor, understand and ultimately predict global change".

The plan is the work of the Committee on Earth Sciences (CES) of the Federal Coordinating Council for Science, Engineering and Technology, an interagency body led by the White House Science Advisor. In essence, it is a manual for policy makers and those who decide how grants from research agencies should be given out.

But by repackaging a variety of research programmes from different agenciees, paid for from different budgets, into one whole, it will also provide a useful weapon in the fight for more funds to support global change research. President George Bush has proposed spending $\$ 191.5$ million on global change research activities in 1990, an increase of 43 per cent over the current year. According to Dallas Peck, director of
Timber Organization in Yokohama. This will make Japan by far the largest contributor to the organization, which aims at promoting sustainable management of tropical rain forests. The agriculture ministry has also asked for several million dollars ( $¥ 394$ million) to establish an information centre for monitoring changes in tropical rain forests using remotesensing technology. But Japan, coming under mounting international criticism as the world's largest importer of tropical timber, has yet to take any measures to reduce its timber consumption.

Even the Ministry of Construction and the Ministry of Transport have requested small budgets to study global environment problems. The construction ministry recently released a report estimating that sea level could rise by 0.5 to 1.5 metres by 2030 if the concentrations of carbon dioxide and other greenhouse gases continue to rise at their present rate. The report calls on the government to add 4-5 metres to shore embankments as a protective measure. The transport ministry estimates a rise in sea level of 1.1 metres and says shore protection work will cost $¥ 3.8$ million million ( $\$ 26,000$ million). The two ministries will carry out further studies of sea-level change and ways of reducing greenhouse gas emissions in housing and transport. David Swinbanks

the US Geological Survey and chairman of the Committee on Earth Sciences, Congress so far appears willing to meet the president's request, and in some cases is providing "an embarrassment of riches." Substantial increases in expenditure are planned further into the future.

"Our Changing Planet: The FY 1990 Research Plan" groups scientific tasks into seven categories and ranks them in order of priority. The study of climate and hydrological systems comes top of the list, and within that category, the role of clouds and of ocean circulation are given the highest priority of all. The two topics are the biggest unknowns in models that attempt to predict whether substantial global warming will take place. Clouds both reflect heat back into space and trap heat in the atmosphere; how the distribution of clouds will be affected by global warming is thus crucial to predicting future temperature changes. The exchange of heat between oceans and atmosphere is dependent upon patterns of ocean circulation that again may be altered by changes in global temperature.

The goal of the research programme is to distinguish between and predict the effects of natural and human-influenced changes, not to set policy on how to slow global change. That will come only after much better predictions are available.

Alun Anderson 